\title{
FIGURY POLITYCZNEJ NIEPOPRAWNOŚCI - SOCJOPOLITYCZNE MITY I SYMBOLE W TWÓRCZOŚCI MIODRAGA BULATOVICIA
}

\author{
ALDONA SZUKALSKA ${ }^{1}$
}

(Poznań)

\begin{abstract}
Słowa kluczowe: symbol, symbolika indywidualna, socjopolityczne mity, mit habsburski, Słowiańszczyzna
\end{abstract}

Key words: symbol, individual symbolics, sociopolitical myths, Habsburg myth, Slavdom

\begin{abstract}
Abstrakt: Aldona Szukalska, FIGURY POLITYCZNEJ NIEPOPRAWNOŚCI - SOCJOPOLITYCZNE MITY I SYMBOLE W TWÓRCZOŚCI MIODRAGA BULATOVCIA. „PORÓWNANIA” 12, 2013, T. XII, s. 139-150. ISSN 1733-165X. „Figury politycznej niepoprawności - socjopolityczne mity i symbole w twórczości Miodraga Bulatovicia", to artykuł poświęcony dziełom serbskiego pisarza czarnogórskiego pochodzenia, a w szczególności jego indywidualnej symbolice z tzw. emigranckiej trylogii, na która składają się trzy powieści: Ludzie o czterech palcach, Gullo Gullo, Peti Prst. Autor za jej pomocą rozprawia się z środkowoeuropejskimi mitami socjopolitycznymi, a także z mitem „wspaniałej Słowiańszczyzny”. Wampir Dracula, świnia Josephine, orzeł Georg, pies Zdeniek i zwierzę Gullo Gullo, to z jednej strony symbole wymyślone przez pisarza i świadomie naruszające polityczną poprawność, z drugiej zaś - pozwalające na stworzenie nowych mitów wyjaśniających fatalizm historii Słowian.
\end{abstract}

Abstract: Aldona Szukalska, FIGURES OF POLITICAL INCORECTNESS - SOCIOPOLITICAL MYTHS AND SYMBOLS IN MIODRAG BULATOVIĆ'S WORK. "PORÓWNANIA" 12, 2013, Vol. XII, p. 139-150. ISSN 1733-165X. 'Figures of Political Incorectness - Sociopolitical Myths and Symbols in Miodrag Bulatović's work' this is an article dedicated to literary output of the Serbian author with Montenegrin background and in particular to his individual symbolism from so called exile trilogy which comprises of three novels: Men of four fingers, Gullo Gullo, Peti Prst. With their help the author is dealing with the Mideast sociopolitical myths and also the myth of 'The Great Slavism'. Vampire Dracula, Pig Josephine, Eagle Georg, Dog Zdeniek and animal

\footnotetext{
${ }^{1}$ Correspondence Address: aldona.szukalska@gmail.com
} 
Gullo Gullo are from one end symbols invented by the author and intentionally intruding political correctness and from the other they are allowing him to create new myths which are explaining the fatalism of Slavic people's history.

Odpowiedź na pytanie o przynależność narodową Miodraga Bulatovicia (1930-1991) sprawia współczesnym badaczom literatury nie lada kłopot. Do twórczego dorobku tego autora roszczą sobie bowiem prawa dwie nacje: serbska i czarnogórska, odpowiednio wpisujące go do swoich własnych kanonów historii literatury. To także, i przede wszystkim, pisarz jugosłowiański - z wyboru mieszkający w Belgradzie i czujący się Serbem, jak i wielu innych Czarnogórców w czasach istnienia federacji. Na tym tle paradoksem może wydawać się fakt, iż w głębi ducha czuł się on właściwie pisarzem europejskim, czerpiącym, nie jak tego oczekiwali rodzimi krytycy, z literatury ludowej i socrealistycznego paradygmatu, lecz z dorobku literatury zachodniej². Dragoljub Stojadinović z prawdziwym oburzeniem zauważył, iż dwie „europejskie“ powieści Bulatovicia: Ludzie o czterech palcach (1975) oraz Gullo Gullo (1983), „najwyraźniej były pisane dla europejskiej publiki i na europejski rynek“" .

W reprezentujących emigrancki cykl ${ }^{4}$ utworach, wspierając się mitologicznym synkretyzmem, pisarz powołał do istnienia niezwykle hermetyczną symbolikę stanowiącą klucz do wymyślonej przez siebie fikcyjnej koncepcji dziejów. Za ich pomocą rozprawił się z środkowoeuropejskimi mitami socjopolitycznymi, a także z mitem „wspaniałej Słowiańszczyzny”. Wampir Dracula, świnia Jospehine, orzeł Georg, pies Zdeniek i zwierzę Gullo Gullo służą stworzeniu nowych mitów wyjaśniających fatalizm historii Słowian, których największym grzechem, jak się okazuje w powieściowym świecie, było przyczynienie się do upadku cesarstwa austro-węgierskiego. Symbole te stanowią kluczowe figury budowanej przez autora mitologii politycznej, poprzez którą poszukuje ukrytych w dziejach sensów. W tej kładącej nacisk na fatalizm słowiańskich losów alternatywnej historii współczesna Europa jawi się jako pole bitwy, na którym toczy się nieustająca walka między siłami ciemności, reprezentowanymi przez dwa systemy totalitarne: faszyzm i komunizm. Za pomocą stworzonych na potrzeby powieści symboli Bulatović na

${ }^{2}$ Miodrag Bulatović za swego duchowego i literackiego prekursora uważał francuskiego poetę Françoisa Villona, czując się spadkobiercą odrzucanej przez paradygmat socrealistyczny kultury Europy Zachodniej.

${ }^{3}$ D. Stojadinović, Miodrag Bulatović: Gullo Gullo. „Književna kritika” 1983, nr 3, s. 121-127 za M. Šukalo, Odmrzavanje jezika. Poetika stranosti u djelu Miodraga Bulatovicia. Beograd 2005, s. 67.

${ }^{4}$ Ostatni cykl twórczości autora poświęcony tematyce emigracyjnej, na który składają się takie utwory jak: Ludzie o czterech palcach, Gullo Gullo i Peti prst. Autor czerpiąc z własnych doświadczeń i obserwacji życia emigrantów, stworzył powieściową fikcję, której nadał jednak dokumentalny charakter. 
nowo ożywia tradycyjne mity polityczne głęboko ukryte w europejskiej świadomości ${ }^{5}$. Wampir Dracula, świnia Jospehine, orzeł Georg, pies Zdeniek i zwierzę Gullo Gullo, to symbole wyjaśniające przyczyny istnienia w powieściowym świecie złowrogiego spisku, którego głównym celem jest dokonanie zemsty na słowiańskich nacjach odpowiedzialnych za bezpowrotne utracenie raju, który u Bulatovicia egzemplifikuje monarchia austro-węgierska.

\section{WAMPIR I BERKSZYR - DWA OBLICZA FASZYZMU}

W Ludziach o czterech placach symbolizujący faszyzm wampir Dracula wraz ze świnią Josephine dokonuje $\mathrm{w}$ równoległym powieściowym świecie krwawej zemsty na Słowianach. Piętnowanie emigrantów i gastarbeiterów przybyłych na Zachód z Europy Środkowej i Wschodniej poprzez obcięcie kciuka jest karą za wspieranie komunizmu, który, jak mniema bohater, odebrał mu dawny bezpieczny świat Austro-Węgier. Przychodzący na świat raz na jedenaście lat berkszyr, jak wyjaśniają powieściowe postacie, symbolizuje ciążące nad Słowianami fatum. To powracające $w$ kolejnych cyklach reinkarnacji wybrane przez los zwierzę zła, które wyróżnia biały kwiat na czole, i które według wierzeń bohaterów zwiastuje nadejście burzliwych czasów ${ }^{6}$. W powieściowym świecie Josephine obok Draculi jest bezpośrednią sprawczynią tragicznego losu przybywających na Zachód emigrantów z Europy Środkowo-Wschodniej i Południowej.

W stworzonej przez Bulatovicia fikcyjnej teorii dziejów marginalizacja roli Słowian w historii jest przede wszystkim karą za wybór i wspieranie ustroju komunistycznego. Jedną z jego pierwszych ofiar okazała się właśnie nosząca imię małżonki Napoleona świnia, która mści się na nacjach w jakikolwiek sposób odpowiedzialnych za powstanie i rozwój tej ideologii. Sprzyjający wzrostowi świadomości narodowej wśród klasy robotniczej komunizm według niej bezpośrednio przyczynił się do rozpadu monarchii austro-węgierskiej i śmierci jej opiekunów arcyksięcia Ferdynanda i jego żony Zofii.

W powieściowej rzeczywistości los Josephine od samego początku, czyli już od chwili jej pierwszych narodzin, jest ściśle związany z ideologią lewicową. Przypadają one na rok 1912, gdy w Rosji, Wielkiej Brytanii i Chinach powstały pierwsze partie socjalistyczne. Tak opisuje przyjście na świat Josephine wampir Dracula:

W tym samym 1912, roku, jedenastego kwietnia, nastąpiło to, co my, weterynarze, filozofowie i kabaliści, nazywamy objawieniem. $\mathrm{W}$ moim chlewie najstarsza maciora z wiedeńskiej gałęzi berkszyrów, Rozalia, wydała na świat jedenaścioro prosiąt. Każde

\footnotetext{
${ }^{5}$ Problem europejskich mitów politycznych porusza K. Kowalski, Europa: mity, modele, symbole. Kraków 2002, s. 23-24.

${ }^{6}$ Zob. M. Bulatović, Ludzie o czterech palcach. Przeł. D. Cirlić-Straszyńska. Warszawa 1983, s. 119.
} 
z nich sam odebrałem, ucałowałem i pobłogosławiłem. Jedenaste prosię, samica, miało między oczami biały kwiat ${ }^{7}$.

Rok 1912, to także data przyjścia na świat Ewy Braun, konkubiny a następnie żony Adolfa Hitlera, który w powieści osobiście powołuje „świnię opatrzności” na symbol faszyzmu:

Bełkotał coś, więc Hitler, po tamtej stronie, musiał krzyczeć, że Josephine to świnia opatrzności. Czarne prosię z białym znakiem na czole, ciągnął, które wreszcie się pojawiło, dokona cudów równych temu, czego on sam: „Kiedy mnie zabraknie, jeżeli mnie zabraknie, zostanie Josephine" tak powiedział ze smutkiem w głosie. Hitler długo tłumaczył swój horoskop polityczny twierdząc, że czarny kolor jego i jej, Josephine, rzuci cień na przyszłość świata ${ }^{8}$.

Momentem przełomowym, który stał się bezpośrednią przyczyną przejścia Josephin na stronę mroku, był dokonany w Sarajewie w 1914 roku zamach. Ulubienica książęcej pary, beneficjentka cesarsko-królewskiej monarchii towarzyszy swoim opiekunom w „wyprawie do Słowian Południowych”, z którymi, jak podkreślali bohaterowie „znów było coś nie w porządku”. Maciora przeczuwając mający nastąpić zamach, wpada w szał. Na „chorą” Josephine, która według osobistego lekarza arcyksięcia padła ofiarą dziwnej zarazy, zostaje wydany wyrok. By choroba nie rozprzestrzeniła się w Austrii, świnia ma zostać zabita. Dzień po egzekucji Josephine z rąk Gavrilo Principa ginie książęca para. Od tego czasu „świnia fatalna" powraca, zwiastując nadejście burzliwych czasów. Jej następujące raz na jedenaście lat narodziny wyznaczają kolejny cykl ziemskiej historii, rozpoczynający się zwykle zdarzeniami mającymi fatalne skutki dla Słowian:

Tak oto świnia szczęścia i spokoju, posłuszeństwa, porządku i pracy stała się symbolem przemocy i zgrozy. Mistycy przepowiedzieli, że - głównie z powodu Słowian Południowych i innych, którzy pójdą $\mathrm{w}$ ich ślady - Josephine będzie pojawiać się na świecie co jedenaście lat. Będą to lata spisków i przewrotów, zamachów i ohydnych morderstw, o jakich przed jej pojawieniem się nie słyszano. Z Josephine było jak ze słońcem, które, wiadomo, co jedenaście lat wchodzi w rok wybuchów i niepokoju. Te dwa cykle stały się odtąd całkowicie zbieżne. Josephine jest słońcem w tej samej mierze, w jakiej słońce jest świnią9.

Obarczani odpowiedzialnością za zamach i wybuch I wojny światowej Słowianie Południowi stają się szczególnym celem zemsty Josephine. Według stworzonej przez Bulatovicia spiskowej koncepcji dziejów, to właśnie rok 1914 wyznacza początek historii komunizmu w Europie. Dla świni i jej zwolenników celem nad-

\footnotetext{
7 Ibidem, s. 121.

8 Ibidem, s. 125.

${ }^{9}$ Ibidem, s. 122-123.
} 
rzędnym staje się więc bezpardonowa walka z popychającą świat ku katastrofie ideologią, jak i ze wszystkimi tymi, którzy w jakikolwiek sposób ją wspierają:

Z drogi prowadzącej w lewo, na którą popychają nas Słowianie, Żydzi i liberałowie, możemy zawrócić ludzkość tylko przy pomocy Josephine. Pomścimy Sarajewo 1914 roku, który według naszej weterynaryjnej nauki oznacza początek komunizmu w Europie!10

Konstruując symbol faszyzmu Bulatović obok kontekstu biblijnego uruchamia także kontekst historyczny. Z jednej strony świnia, to zwierzę nieczyste, w które w Ewangelii wg św. Łukasza wstępują wygnane z opętanego człowieka diabły, z drugiej zaś przewrotna aluzja do postaci Richarda Waltera Darré, ministra III Rzeszy do Spraw Żywności i Rolnictwa. Ten stojący przez pewien czas na czele Głównego Urzędu do Spraw Rasowych i Przesiedleńczych SS i odpowiedzialny za realizację projektu stworzenia rasy aryjskiej, jak i stwierdzenie, iż kobiety to marzycielsko-przeżuwające zwierzęta domowe, urzędnik, z wykształcenia był teoretykiem hodowli świń11. Recytowany przez więźniów Draculi fikcyjny Podręcznik hodowli świń Niezależnego Państwa Chorwackiego autorstwa dra Kreszimira Maslovaricia jest ironiczną parafrazą programu rasowej odnowy jego autorstwa:

\begin{abstract}
„Punkt piąty, paragraf pierwszy - zaczął Marasz rozmazując krew po twarzy ręką pozbawioną kciuka. - Duże czarne litery: Białe świnie niemieckie, a w nawiasie: Biała, Szlachetna i Uszlachetniona. Od nowego wiersza: Biała, szlachetna i krótko ucha świnia niemiecka szczecinę ma, jak wynika z nazwy, białą. Jest to wcześnie dojrzewająca świnia typu mięsno-słoninowego. Bardzo przypomina wielką białą świnię. Biała szlachetna świnia niemiecka, o której mowa, rycina dziesiąta, jest również dużą świnią. Od wielkiej białej świni niemieckiej różni się krótszym tułowiem, przecinek, ma także krótsze nogi. W ciągu rocznego prawidłowego chowu biała świnia niemiecka osiąga wagę od stu pięćdziesięciu do stu osiemdziesięciu kilogramów. Maciora wydaje na świat od dziesięciu do dwunastu prosiąt ${ }^{12}$.
\end{abstract}

W powieści Ludzie o czterech placach obok Josephine symbolem faszyzmu jest także jej opiekun wampir Dracula13, który podobnie jak jego podopieczna w niepodległościowych dążeniach Słowian upatruje głównej przyczyny klęski swej ukochanej ck monarchii. W efekcie dokonuje na jej przedstawicielach symbolicznego aktu zemsty poprzez obcięcie im kciuka.

Bulatović, odwołując się poprzez fikcyjne symbole do realnych zdarzeń, na nowo ożywia polityczne mity i dokonuje restytucji mitu habsburskiego jako złote-

${ }^{10}$ Ibidem, s. 130.

11 Zob. M. Szczygieł, Gottland. Wołowiec 2003, s. 53.

12 M. Bulatović, Ludzie o..., op. cit., s. 105.

${ }^{13}$ Szczegółowe omówienie znaczeń symbolicznych wampira pojawia się w poświęconym ikonie kulturowej rozdziale pracy doktorskiej mojego autorstwa. 
go wieku Europy. Konstruując postać wampira sięga więc nie tylko do literatury i kina grozy, ale także po fakty historyczne, by jak najbardziej uwiarygodnić tę postać w oczach czytelnika:

Pan, o którym mowa, jest Anglikiem. To Anglik, potwór z tej Wyspy wampirów! Istnieje wiele jego równolegle krążących autobiografii, ale prawie we wszystkich nazywa siebie Ryszardem, Britem, Albionem. Kiedyś wpadł mi w ręce niekompletny egzemplarz jednego z jego kalendarzy. Ryszard Świńskie Serce niemal we wszystkich językach europejskich, łącznie z martwymi, opisuje tam swój wiek XIV. Jako zajadły Wyspiarz wszelkimi możliwymi sposobami starał się pogrążyć Europę, wszystkie jej dobra i wartości. Rozniecał niezgodę, szerzył intrygi, wywoływał zamieszki. [...] Ryszard Świńskie Serce wierzył w Turków, którzy mieli zniszczyć Europę, tak jak w roku 1351 wierzył w dżumę. Pouczył Seldżuków, jak w roku 1389 na Kosowym Polu mają rozbić nas, przeżartych i pijanych Serbów! W cztery lata później, w 1393, Turcy niemal w ten sam sposób ujarzmiają Bułgarów. W roku 1394 lub 1395 papież Bonifacy IX, na prośbę zdjętego strachem króla Węgier Zygmunta Luksemburczyka, zezwala na rozpoczęcie wyprawy krzyżowej przeciwko Azjatom. Ta wojna z islamami trwa do dziś. Ryszard był i pozostał jej przeciwnikiem ${ }^{14}$.

\section{GULLO GULLO A SPRAWA WALKI ZE ZGNIŁYM ZACHODEM}

Innym fikcyjnym symbolem powołanym do istnienia na potrzeby stworzonej przez Bulatovicia koncepcji historiozoficznej jest tajemnicze i według powieściowych postaci „mitologiczne” zwierzę Gullo Gullo. Patronuje ono noszącej jego imię międzynarodowej organizacji, która ponosi odpowiedzialność za przeprowadzone w Europie Zachodniej terrorystyczne zamachy. Mająca lewicowy charakter partyzancka bojówka porywa i morduje przedstawicieli świata kapitalizmu wyzyskujących klasę robotniczą. Założycielami i członkami uznawanego za organizację terrorystyczną ruchu jest grupa męczenników-emigrantów, dokonujących osobistego aktu zemsty na zdemoralizowanych przedstawicielach "zgniłego Zachodu”.

Propagująca idee rewolucyjne organizacja Gullo Gullo, która przypomina socjalistyczną Międzynarodówkę, w głoszonej przez siebie ideologii zdradza źródło swego natchnienia. Jeden z członków guerilli, tak wyjaśnia przesłanie ruchu: „Gullo Gullo to imię krwiożerczego i dobrego zwierzęcia, a jednocześnie nazwa ruchu kidnaperskiego, lecz także wyzwoleńczego. Nie sudeckiego, nie bałtyckiego, nie tyrolskiego, ale - światowego! Gullo Gullo jest więc zwierzęciem, chciałem powiedzieć ideą, problemem światowym, symboliczno-politycznym zwierzęciem, które poprzez krew i poezję przynosi wolność, sprawiedliwość..."15.

\footnotetext{
14 M. Bulatović, Ludzie o..., op. cit., s. 222-223.

${ }^{15}$ M. Bulatović, Gullo Gullo. Przeł. D. Cirlić-Straszyńska. Warszawa 1989, s. 93.
} 
Lewicujący partyzanci w rzeczywistości prowadzą bezwzględną walkę z przedstawicielami Zachodu. Polują i uśmiercają odrażających w swym kulinarnym, moralnym i seksualnym rozpasaniu kapitalistów, którzy bogacą się na krzywdzie ubogich. Reprezentują ich pławiący się w grzesznym luksusie bogacze, jak Kurt Bodo Nossack czy perwersyjny Pinto. Ten pozbawiony skrupułów pederasta i pedofil, który bez opamiętania konsumuje kulinarne przysmaki w przerysowanym i rodem z Rabelaisowskiej groteski portrecie, sprowadzony zostaje do zwulgaryzowanych czynności fizjologicznych. Natomiast miłujący wolność i poezję młodzi idealiści z Gullo Gullo naprawiają świat, usuwając z niego takie właśnie odrażające kreatury. Ich manifest formułuje sam Luther:

Na małych ekranach oglądaliśmy, jak dymią i wylatują w powietrze madryckie cukrownie i lizbońskie magazyny kakao, gumy do żucia, makaronu. Marzyliśmy o prawdzie, płomieniu, naprawianiu świata ${ }^{16}$.

Bulatović zderza jednak postawę romantycznego bojownika walczącego o dziejową sprawiedliwość i idealizm młodych członków organizacji z brutalnością stosowanych przez nich metod. By uwiarygodnić istnienie Gullo Gullo, autor umiejscawia guerillę wśród prawdziwych organizacji terrorystycznych takich jak: baskijska ETA, włoskie Czerwone Brygady czy chorwaccy ustasze Ante Pavelicia. Dodatkowo wprowadza do powieści współczesne sobie realia:

A więc nie zapominajcie: Gullo Gullo to cud zoologiczno-polityczny, pojęcie, zjawisko lat siedemdziesiątych i osiemdziesiątych; jak słyszycie, jest to zrazem imię zwierzęcia, które uznaliście za martwe, a następnie w ciągu dziejów, zrobiliście z niego najbardziej krwiożerczą, bezwzględną, mściwą bestię, i jest to wreszcie nazwa ruchu porywaczy, do którego, zapamiętajcie już raz, należy nasza guerilla... ${ }^{17}$

Gullo Gullo, to tajemnicze zwierzę o mitycznej proweniencji, a zarazem znak elitarnej organizacji kidnapersko-wyzwoleńczej, gdyż autor wprowadza je do powieści jako „symbol dla bohatera”. Jej członkowie tak opisują swój symbol:

Ogoniaste, krwiożercze, nienasycone zwierzę z Dalekiej Północy, Vielfrass, wszystkojad, wszystkożer! Po węgiersku rozsomák! Bestia nad bestiami, zaraza, potwór, który za jednym zamachem wyrywa serce reniferowi $!^{18}$

Na potrzeby powieści Bulatović tworzy nawet od podstaw drobiazgową ikonografię świętego zwierzęcia męczennika:

Na skórzanym kołnierzyku nosił Luther miedziany amulet z wyobrażeniem zwierzęcia Gullo Gullo, przypominającego kunę. Gullo Gullo na amulecie Luthra szczęki miał

\footnotetext{
16 Ibidem, s. 135.

17 Ibidem, s. 50.

18 Ibidem, s. 47.
} 
rozwarte, pazury niezwykle długie i krzywe, wysunięte zapewne w stronę ofiary, wypolerowany członek oraz nieproporcjonalnie duże, niebezpieczne jądra ${ }^{19}$.

Dodatkowo wyposaża fikcyjny symbol w niezwykle skomplikowaną i czerpiącą z różnorodnych mitologii genealogię. Dla potrzeb czytelnika mityczny rodowód tajemniczego zwierzęcia autor rekonstruuje w świętej księdze organizacji tzw. Nowej Biblii oraz w dwugodzinnym programie telewizyjnym nadawanym przez organizację bez zezwolenia. We fragmencie będącym parafrazą Księgi Genezis, ale i greckiego mitu o zabójstwie Kronosa, „święte zwierzę” Gullo Gullo przedstawione zostaje jako praprzyczyna powstania mrocznej historii.

W powieści mity o Gullo Gullo przybliża czytelnikowi m.in. Kurt Bodo Nossack. Zepsuty kapitalista słowiańskiego pochodzenia, który po porwaniu przez terrorystyczną organizację doznaje duchowej odnowy i staje się zagorzałym interpretatorem idei krwiożerczego rosomaka. W toku akcji streszcza on opisaną w Nowej Biblii historię zwierzęcego męczennika:

Zwrócili tylko uwagę, że pierwsze zdanie Nowej Biblii brzmi: „Na początku było nie słowo i nie strach, ale na początku była otchłań, pustka i Gullo Gullo, zwierzę dobre i pogodne, mądre i szlachetne, piękne jak słoneczny dzień, jak przemoc, zwierzę święte, tak jak niezaprzeczalnie święty był kiedyś krzyż..."

$[\ldots]$

Stało się to w jednej chwili, mówię, ważnej jak moment zapłodnienia śmierci. Wystrzelił płomień, koloru i kształtu ogona naszego zwierzęcia. Sądząc po wielkim jego rozmachu, musiał pochodzić z samego wnętrza świata, z kamienia, który oparł się wodzie. Płomień rozpłatał wszechmocny dotychczas kałdun pary na dwoje na troje na pięcioro, i dobiegły mnie odgłosy obozowej rzezi, pisk polskich dzieci, krzyk kruków. Z kałduna trysnęły kiszki nerki jądra, działa strzały druty, buchnął odór ropy mózgu fekaliów, zaistniała historia ${ }^{20}$.

Dla terrorystycznej organizacji miłujące wolność „mityczne” zwierzę staje się także symbolem ciemiężonego przez bezwzględnych kapitalistów emigranta. Według członków Gullo Gullo dzieliło ono niegdyś ich los:

Gullo Gullo, to też emigrant - zapewniła Hanaff podtrzymując dentystę, żeby nie upadł. - Gullo Gullo to najstarszy, najbardziej prześladowany emigrant, o jakim dziś wiadomo. Wybiła więc godzina, by Gullo Gullo rozwiązał pewne sprawy w tym brudnym, plugawym, kapitalistycznym świecie! [...] Gullo Gullo, odszczepieniec i mściciel! Gullo Gullo, emigrant i męczennik, taki jak pan, Herr Szabó! Gullo Gullo, symbol! ${ }^{21}$

\footnotetext{
19 Ibidem, s. 48.

${ }^{20}$ Ibidem, s. 54, 165.

${ }^{21}$ Ibidem, s. 47.
} 
Podobnie jak w przypadku Josephine, celem licznych odwołań zarówno do pogańskich jak i chrześcijańskich mitologii, jest uwiarygodnienie istnienia symbolu Gullo Gullo. Dla zabawy autor wyposaża go nawet w apokryficzną i zdaniem jednego z członków organizacji - błędną, genealogię. Według ludowych wierzeń ma on bowiem wampiryczny rodowód:

Mieszkańcy Rosenburga i każdego Burga, mieszczanie, wy przeklęte alpejskie hieny, wy, którzy świętemu zwierzęciu i męczennikowi Gullo Gullo, nadaliście pogardliwe przezwisko Vielfrass, wy, dla których jest on Żarłokiem, Obżartuchem, Wszystkojadem, wy, którzy nazywacie go Glouton, Glutao, Glutton artico, Giutone, wy sępy z drugiej półkuli, dla których on, Gullo Gullo, jest tylko Wolverine, wy którzy nazywacie go Zolelan, Nahim, Pamfagos, i wy z południa jebanego świata, krwiopijcy Arabowie, dla których nasza gwiazda, nasz sztandar to zwykły Ghoul, czyli wampir, wilkołak, potwór wyciągający z groźnym rykiem trupy z grobów i rozdzierający je na kawałki [...] $]^{22}$.

\section{GEORG AUSTRIAK - PTAK HISTORYCZNY, PTAK NASZEGO LOSU}

W powieści Gullo Gullo obok tytułowego zwierzęcia kolejnym wymyślonym przez autora symbolem zoomorficznym jest orzeł. Jak wyjaśnia jego właściciel emigrant doktor Ott, Georg Austriak, to „ptak historyczny, mityczny, polityczny, ptak klęski, ptak naszego losu"23. Także i w tym przypadku Bulatović odchodzi od konwencjonalnych przedstawień. Będący godłem wielu państw orzeł, to tradycyjnie wizualny znak patriotyzmu, walki o wolność i niepodległość 24 . Wymieniany obok wilka i kruka jako zwierzę bitwy 25 orzeł symbolizuje tryumf, potęgę militarną, moc, waleczność, wzniosłość, szybkość i siłę26. Zaprzeczeniem tych wyobrażeń jest na pół ślepy i cierpiący na czeski świerzb orzeł Georg - symbol dawnej, minionej już świetności Austrii. Jego kondycja jest wizualną metaforą, diagnozą tego, co pozostało z dawnej potęgi militarnej ck monarchii. Wyryta na obrączce ptaka cyfra 1866, to data przegranej przez Austriaków wojny z Prusakami o utrzymanie hegemonii w Europie Środkowowschodniej. Wyznaczyła ona kres marzeniom o stworzeniu monarchii od Bałtyku aż po Adriatyk. Pochodzący z Sudetów Niemiec dr Ott, który opiekuje się schorowanym orłem, odwołuje się do rzeczywistych wydarzeń historycznych, w których umiejscawia swojego podopiecznego.

22 Ibidem, s. 49.

23 Ibidem, s. 68.

24 Zob. D. Dąbrowska, Motyw orła i wrony w poezji stanu wojennego, w: Literacka symbolika zwierząt. Pod red. A. Martuszewskiej. Gdańsk 1993, s. 182-183.

25 Zob. A. Martuszewska, Literackie zwierzyńce: wstęnna lustracja. W: Literacka..., op. cit., s. 14.

${ }^{26}$ Zob. W. Kopaliński, Orzet, [hasło], op. cit., s. 803-804 oraz T. Jelonek, L. Rotter, op. cit., s. 79. 
I tak według niego Georg - symbol dawnej potęgi militarnej Austrii - towarzyszył w czasie bitwy wojskowemu przywódcy jako żywy talizman:

Tylko wtajemniczeni wiedzą o istnieniu Georga, żywego talizmanu, ale mało kto wie, gdzie przebywa, mówiąc dokładniej, bieduje. Jako jedenastomiesięczny orlik, z obrączką i wyrytą na niej datą, Georg siedział na ramieniu Rottmüllera, który pod Hradcem w pobliżu Pragi, stał na czele najsilniejszej wówczas w Europie armii austriackiej. Dowódca Prusaków, rycerz ten a ten, anonim nie miał na ramieniu nic prócz epoletów, a jednak nas pokonał. Wyrżnął! My, Austriacy, straciliśmy ponad czterdzieści tysięcy ludzi, i to jakich, a zwycięzcy, te przybłędy, dwa razy mniej! Wszechniemiecka krew lała się strumieniami. Austriacki symbol, Georg, z ramienia Komendanta, Rottmüllera, wpadł w ohydne pruskie łapy. Jakimś cudem jednak został odbity, choć wielu zapłaciło za to życiem. Dobrze, że mamy chociaż jego, symbol zoopolityczny, skoro nie mamy monarchii K. und K. od Bałtyku aż po Adriatyk! ${ }^{27}$

Ukrywany przez doktora $\mathrm{w}$ komórce przez ostatnie dwadzieścia siedem lat orzeł, to nie tylko poddany deprecjacji symbol minionej świetności, siły i potęgi dawnej monarchii, ale także skrywanych głęboko przed światem szowinizmów. Jest on kwintesencją austriackiej duszy, w której niegdyś wykiełkował faszyzm, i który, jak uważa autor, choć się temu oficjalnie zaprzecza, nadal w niej istnieje. Jednak jak podkreśla dr Ott, w rzeczywistości przedstawionej rola Georga nigdy nie została $\mathrm{w}$ pełni wykorzystana. Klęska monarchii austro-węgierskiej jest w powieści Bulatovicia mistyczną zapowiedzią przyszłego upadku Trzeciej Rzeszy. Według doktora w alternatywnej historii tylko obecność orła mogła opóźnić o stulecie lub dwa zdobycie Berlina:

W roku 1914 nie doszłoby do krwawego cyrku w Sarajewie, gdyby Arcyksiążę Franciszek Ferdynand i Sophie zamiast ze świnią losu i przemocy, Josephine, wybrali się na Słowiańskie Południe z Georgiem! On, Georg, mógł zmniejszyć klęskę pod Stalingradem, Kurskiem, o stulecie lub dwa opóźnić upadek świętego miasta Berlina!28

\section{ZDENIEK - PIES POLITYCZNY, KTÓRY NIE SZCZEKA}

Czarny owczarek Zdeniek z Gullo Gullo podobnie jak Georg jest indywidualnym symbolem stworzonym na potrzeby powieści. To żartobliwe, ale i nieco uszczypliwe przedstawienie politycznych poglądów oraz życiowej postawy Czechów, gdyż tym, co wyróżnia psa, to fakt, iż w ogóle nie szczeka. Doktora Otta z noszącym słowiańskie imię i hodowanym przez niego zwierzęciem łączy szczególna więź - wspólne sudeckie pochodzenie, a także emigrancki los.

\footnotetext{
27 M. Bulatović, Gullo Gullo, op. cit., s. 69.

${ }^{28}$ Ibidem, s. 69.
} 
„Pan się go boi? Dlaczego?"

„Dlatego, że nieszczekanie Zdeńka, spowodowane najwyraźniej tęsknotą, nostalgią, w pewnej mierze wyraża również moją własną emigrancką tragedię, mój kompleks. Wierzcie albo nie. Zdeniek i ja pochodzimy z tej samej sudeckiej wsi..."29.

Cierpiący na dziwną przypadłość trzyletni Zdeniek jest także symbolem losu słowiańskiego emigranta. Jak wyjaśnia właściciel dr Ott, dziwna przypadłość psa ma swoje źródło w jego tragicznej uchodźczej przeszłości. Zdeniek jako trzymiesięczny szczeniak był bowiem świadkiem zamordowania przez niemiecką i czeską straż graniczną dysydentów nielegalnie przekraczających górską granicę. To, co spowodowało milczenie psa, leczący go doktor Grabski, diagnozuje jako głęboki polityczny szok. Jego powrót do zdrowia uzależnia zaś od przyszłego rozwoju sytuacji w Europie i na całym świecie, ale dodaje również, że cierpiące na „,zeski kompleks” zwierzę być może jeszcze niespodziewanie zaszczeka: „Zdeniek być może zaszczeka, a wtedy będzie szczekał i za siebie, i za inne psy, które są w jeszcze większym politycznym szoku, w stanie niebezpiecznej śpiączki..."30.

\section{CZEKOLADA A SPRAWA KAPITALIZMU}

Pojawiająca się w powieści Gullo Gullo i uchodząca niegdyś w krajach socjalistycznych za towar luksusowy czekolada symbolizuje znienawidzony przez członków guerilli kapitalizm. W powieściowym świecie wlewanie w siebie ciepłej czekolady obrazuje nie tylko zbytek i kulinarne rozpasanie, ale $\mathrm{i}$ istnienie społecznej nierówności:

Jonie Txiki, Jonie Mały i wszyscy pozostali, wy, którzy opychacie się tym żarciem, którzy wlewacie w siebie ciepłą czekoladę, wino i szampan, przechylcie trochę wasz stół i zrzućcie jakiś okruch! Jesteśmy odcięci od świata, zabrakło nam wody i żywności, a nasz Pablo umiera w męczarniach! Gdyby przyjechał Salvador, gdyby tu był, nie prosilibyśmy i nie żebrali, sami byśmy sobie wzięli! Zrób coś, Jonie Mały, pozwól nam się przekonać, czy jesteście jeszcze ludźmi i Baskami!31

Wybierając czekoladę na symbol nadmiernego luksusu świata Zachodu, Bulatović zmierza w stronę absurdu i groteski. Jeden z powieściowych kapitalistów Jonie Txiki ma czekoladowe wnętrzności, podczas gdy fabrykant, właściciel jedenastu fabryk, Aldo Moretti sika czekoladą. Także dokonywane przez organizację Gullo Gullo zamachy są przede wszystkim związane z zakładami produkującymi czekoladę. I tak na przykład lewicowi terroryści detonują ładunki wybuchowe

\footnotetext{
29 Ibidem, s. 70.

30 Ibidem, s. 72-73.

31 Ibidem, s. 32.
} 
w magazynie Coroniniego, wysadzając w powietrze kilka ton czekolady w proszku. Jeden z bohaterów tak opisuje skutki zamachu: „chmura kakaowa rozpostarła się nad kilkoma ulicami w pobliżu dworca i każdy mógł zażywać kakao, ile tylko chciał" 32 .

Reprezentantem zepsutego świata kapitalizmu, który bezlitośnie wyzyskuje słowiańskich emigrantów jest Herr Bodo Nossack. Przedstawiciel Gullo Gullo zarzuca mu przedmiotowe traktowanie ludzi:

„Wszyscy zależymy od pana, Herr Nossack. Żyjemy w mieszkaniach, które są pana własnością. W domach, w których co druga cegła jest pana cegłą. Robimy i czytamy pańskie gazety. Pieniądze, którymi obracamy, są pana pieniędzmi. Jesteśmy nawet częścią tych pieniędzy. Jesteśmy pana towarem. Pana wartością dodatkową, stopą wzrostu gospodarczego. Nasza przyszłość spoczywa w pańskim ręku. My, którzy pracujemy w Pana przedsiębiorstwach, szpitalach rzeźniach, nie chcemy iść na ulicę!"33

Czekolada jako symbol kapitalizmu i zbytku przewija się nawet w wygłoszonym przez Gullo Gullo manifeście:

„Mieszczanie i drobnomieszczanie całego świata - ciągnął - lewicowi i prawicowi, prawicowi i lewicowi, niszczyciele wszystkiego, co uczciwe, sprawiedliwe i pełne głębokiego sensu, wy, którzy dławicie się ideologią ciasta, sera i czek o l a d y [podkr. - A. Sz.], religią własnych fekaliów, zapamiętajcie sobie: Gullo Gullo dopadnie waszych głów, kiszek; zapamiętajcie: jego pozbawione wszelkich praw imię pisze się tylko w jeden sposób: pierwsze litery duże, jakby chodziło o twórcę, podwójne „L”, to znaczy podwójna wolność; zapamiętajcie: imienia Gullo Gullo się nie tłumaczy, tak jak nie tłumaczy się uniwersalnej moralistycznej metafory, myśli, zasady; zapamiętajcie: imię Gullo Gullo najsurowiej zabrania się zakuwać w cudzysłów oraz podporządkowywać jakiejkolwiek burżuazyjnej czy proletariackiej interpunkcji34.

W powieściowym świecie żyjący w luksusie i bogactwie kapitaliści produkują dla innych czekoladę - kulinarny symbol dobrobytu i zbytku zachodniego świata oraz niczym nieuzasadnionego nadmiaru. W dramatycznym apelu członków guerilli fabrykanci zostają przestawieni jako zdegenerowane i zdemoralizowane monstra:

Wówczas, za Jonem Małym, zwróciło się ku nam wszystkich dziewięćdziesiąt ryjów, cały kapitalizm. Panowie $\mathrm{w}$ damskich sukniach, $\mathrm{z}$ nadmiernie kudłatymi lub wygolonymi łbami, cukiernicy miodownicy słodycznicy z wystającymi jabłkami Adama, menażerowie ze scukrzonymi wargami uszami oczyma, pederaści mineciarze dupojebcy o proteinowych cyckach i wyperfumowanych tyłkach, Portugalczycy, Holendrzy, Francuzi $\mathrm{w}$ dopasowanych marynareczkach, jak też zamorscy goście, wypudrowani

\footnotetext{
32 Ibidem, s. 155.

33 Ibidem, s. 180-181.

${ }^{34}$ Ibidem, s. 49-50.
} 
czekoladą. I damy, mnóstwo dam, z wypielęgnowanymi gęsimi szyjami i łokciami, z obnażonymi wzgórkami Wenery pokrytymi koźlęcym futerkiem, damy w naszyjnikach z czekoladowych kutasików i bez nich, damy z podnieconymi kolanami brodawkami dziurkami, stare i młode damy z różami zerwanymi w ogrodzie Jona Małego, wetkniętymi w skórę, koki, w bransoletki ${ }^{35}$.

Guerilla z niepokojem odkrywa, iż niebezpieczeństwo „czekoladyzacji” zagraża także przybywającym na Zachód z Europy Środkowowschodniej emigrantom. Jedną z jej ofiar jest emigrant Węgier Arpad Szabó. Ten, jak go nazywają członkowie organizacji, "sczekoladyzowany niewolnik” de facto pełni w domu Nossacka funkcję służącego:

Szabó pchał stoliczek z tabliczkami czekolady, z kulkami czekolady, z czekoladowymi minami. Pochylony, z czekoladowymi oczami, z uszami, które ledwo się trzymały niewolniczej i emigranckiej, czekoladowej czaszki. Szabó przypominał długonogie uosobienie klęski, śmierć kulejącą na ścieżce. Ubrany na biało, czekoladowy Szabó, w czapeczce jak u oprawcy z trupiarni, wokół szyi miał okręconego węża ${ }^{36}$.

Analiza symboliki w twórczości Bulatovicia ukazuje kierunek artystycznej ewolucji tego pisarza, który w sferze poetyki dokonał wolty polegającej na przejściu od stylizacji mitycznej (Czerwony kogut..., Bohater na ośle) do zapisu scenariuszowego (Ludzie o czterech placach, Gullo Gullo). W swoich pierwszych zbiorach opowiadań Đavoli dolaze (Diably nadchodza) z 1956 roku oraz Vuk $i$ zvono (Wilk i dzwonek) z 1958 roku, a także powieści Czerwony kogut leci wprost do nieba (1964), przede wszystkim czerpał $\mathrm{z}$ tradycyjnej symboliki biblijnej. Przywołując liczne konteksty, ujawniał swą wielką erudycję, jak i głębokie zakorzenienie w kulturze europejskiej. Jednocześnie wykorzystywał symbol jako sposób wyrażania niewyrażalnego i poruszania istotnej problematyki egzystencjalnej. Z czasem w utworach takich jak: Ludzie o czterech palcach (1975) oraz Gullo Gullo (1983) porzuca gotowe rozwiązania na rzecz niezwykle groteskowych, wymyślonych przez siebie symboli indywidualnych, za pomocą których wyjaśnia własną koncepcję słowiańskich dziejów. I tak w ostatnim, całkowicie odmiennym pod względem poetyki i tematyki od dwóch poprzednich, etapie twórczości zmienia także technikę wizualizacji, by za pomocą autorskiej symboliki zoomorficznej na nowo ożywić ukryte w europejskiej świadomości mity socjopolityczne.

Bulatović niechętny socrealistycznemu paradygmatowi, w którym świadomie odcinano się od dorobku literatur Europy Zachodniej, i który siłą narzucali mu krytycy jugosłowiańscy, prowokacyjnie wymierzył ostrze swej groteski w rodzime

\footnotetext{
35 Ibidem, s. 33.

36 Ibidem, s. 41.
} 
mity. Uderzył przede wszystkim w sakralizowany mit komunistycznej partyzantki (Bohater na ośle), ale także romantyczną koncepcję słowiańskich mesjanizmów (Wojna byta lepsza, Ludzie o czterech palcach). Wyklęty, lekceważony i odrzucony przez środowiska twórcze we własnym kraju Bulatović, ostatecznie wybiera emigrację. Jego droga prowadzi najpierw do Słowenii, później do Niemiec Zachodnich, gdzie udaje mi się zdobyć upragnione uznanie. W tym czasie, odwołując się do własnych doświadczeń, jak i zebranej przez siebie dokumentacji, tworzy poświęcony życiu emigrantów cykl powieściowy. Również tym razem, wierny swej buntowniczej naturze, idzie pod prąd politycznej poprawności. Stworzona przez niego symbolika autorska ukazuje $\mathrm{w}$ niezwykle krzywym zwierciadle moralne zepsucie i niczym nieuzasadnione poczucie wyższości mieszkańców Zachodu. Niepokorny autor wykorzystuje ją także, by zdekonstruować żywotny niegdyś mit cesarstwa austro-węgierskiego jako słowiańskiego raju, poprzez ukazanie go w roli kolebki europejskiego faszyzmu. 